\title{
The Effect of Mechanical Vibration on Casting Properties of Grain Refined A356 Alloy
}

\section{Abdulhadi KOŞATEPE ${ }^{1}$, Ahmet KABİL ${ }^{2}$}

\begin{abstract}
In this study, it was aimed to have the desired microstructure at low cost (fine and spherical) of aluminum alloys which have a wide usage in engineering materials and a wide variety of production methods. A15Ti1B was added to the A356 aluminum alloy melted in a $700{ }^{\circ} \mathrm{C}$ resistive furnace with Ti content of $0.1,0.2$ and $0.3 \%$ by weight. Casting was performed on a 20,10 and $5 \mathrm{~mm}$ cross-section metal mold placed on a vibration table producing a mechanical vibration of $50 \mathrm{~Hz}$ fixed frequency and $1.5 \mathrm{~mm}$ amplitude, vibration and non- vibration. Microstructural investigations on the cross-sections of the final casting products were carried out in two stages. In the first step, the distance between the secondary dendrite arms (SDAS) and the length of the secondary dendrite arms (SDAL) were measured on the images taken by optical microscope. In the second stage, EDS analysis was performed by SEM. Hardness measurements of the samples were made by Brinell method and the relationship between the microstructure and hardness values was tried to be revealed. SDAS and SADAL values decreased due to Ti content and section thickness. Accordingly, hardness tends to decrease as it progresses from thin section to thick section.
\end{abstract}

Keywords: A356 alloy, grain refining, sdas, sdal, mechanical vibration

1 Abdulhadi KOŞATEPE (Orcid ID: 0000-0002-7767-4981),Ağrı İbrahim Çeçen Üniversitesi, Patnos Meslek Yüksekokulu, Ağrı, Türkiye

2 Ahmet KABİL (Orcid ID: 0000-0001-9078-8652), Yıldız Teknik Üniversitesi, Metalurji ve Malzeme Mühendisliği, İstanbul Türkiye

*Sorumlu Yazar/Corresponding Author: Abdulhadi KOŞATEPE, akosatepe@agri.edu.tr 


\section{INTRODUCTION}

In view of advancing technological needs, cost, quality, safety and aesthetics are very important in almost all areas, especially in the automotive and aerospace industries. Although these parameters are closely related to each other, the need to keep costs to a minimum despite the increase in safety and quality forms the basis of engineering research and production methods. Along with the superior properties of aluminum and its alloys, the differences between the alloys stand out one step further. For example, the A356 (Al7Si0.3Mg) alloy in the group of Al-Si alloys are one of the most preferred alloys in casting ( Koşatepe et al., 2019). The alloy is preferred because of its excellent pourability, high thermal conductivity, high specific strength, low density and well corrosion resistance. ( Yüksel, 2018 ). The chemical, physical and mechanical properties of aluminum casting alloys are directly related to the microstructure of the alloy. The homogeneity of the casting product is ensured by the fact that the microstructure is fine-grained, the secondary phases are homogeneous and spherical morphology and the micropores are kept at the lowest level. Significant improvements in properties such as hardness, toughness, yield strength, surface roughness and machinability are observed in casting alloys with fine grain microstructure ( Kurban, 1997 ).

The combined effect of vibration and Al-Ti-B master alloy addition on the casting product, which is one of the grain refining methods, is among the subjects worthy of research. The principal vibration effects were found to be related to reduction of grain size by supporting nucleation, reduction of shrinkage pores due to improved metal feeding, and production of a more uniform casting structure (Chirita, 2009 ). Mechanical vibration method, which is one of the vibration application methods, has been shown to be relatively less costly than electromagnetic and ultrasonic vibration methods ( Çolak and Kay1kc1, 2009 ). It has been found that mechanical vibration applied during the casting process can provide localized cooling by drawing heat from the inside of the molten alloy ( Edwars et al., 2004; Sayuti, 2016 ). In addition, by breaking the needle-like dendrite arms by vibration, it has caused the dendrite to become more spherical form in addition to forming a nucleus for new grains ( Lieserberg et al., 2001; Peres et al., 2004; Tunçay, 2012 ). Thus, a substantially fine-grained microstructure can be obtained depending on the amplitude, frequency, and mold wall thickness of the vibration ( Hong-min, 2014; Jiang, 2014). Master alloys used as grain refiners are added to the liquid metal to obtain a finer grain microstructure. Master alloys reduce grain size and increases the grain boundaries ( Braynt et al., 1990; Ibarra, 1999 ). The increased number of grain boundaries improves the mechanical properties while at the same time decreasing the level of impurity (Uludağ, 2016 ).

A15Ti1B master alloys are widely used as a grain refiner in the form of a rod. Grain refiner master alloys are added to the liquid metal in trace amounts. Ti and B react with aluminum atoms to form a large number of $\mathrm{Al}_{3} \mathrm{Ti}$ and $\mathrm{AlB}_{2}$ intermetallic compounds in the liquid metal. Since these compounds have high melting points, they serve as solid nucleation centers in liquid aluminum and provide grain refining ( Çolak and Balcı, 2016 ). Emphasis is placed on the morphological changes of the primary aluminum phase of the cast alloy, which are exposed to different mechanical vibration levels at various values of the pouring temperature and solid fraction ( Limmaneevichitr , 2009 ). In a similar study, although the morphology and distribution of eutectic silicon in the aluminum-silicon alloy system have shown the most important influence on the change in mechanical properties, the size and morphology of the primary aluminum phase and the porosity distribution may also play an important role ( Puga et al., 2011 ).

In this study, A15Ti1B master alloy was added to the A356 liquid alloy with a Ti content of 0.1, 0.2 and $0.3 \%$ by weight, followed by casting into the step mold without vibration. In order to examine 
the effect of vibration, liquid metal was prepared with the same procedure, then casting was performed with applying mechanical vibration for 90 seconds at $50 \mathrm{~Hz}$ frequency and amplitude of $1.5 \mathrm{~mm}$. The microstructure and hardness values of step mold sections of the samples were compared.

\section{MATERIALS AND METHODS}

Al7Si0.3Mg primary aluminum alloy was used in each casting as charging material. The chemical composition of the aluminum nugget is components in Table 1.

The melting process was carried out in a $\mathrm{SiC}$ crucible at $\sim 730^{\circ} \mathrm{C}$ in a resistance furnace. As shown in Figure 1, the metal melted in the resistant furnace used for melting grain refining master alloy was added to the liquid metal and allowed to dissolve for 20 minutes. This is due to the fact that the master alloy added to the metal melt gives time to dissolve completely in the liquid metal and is homogeneously dispersed ( Çolak and Kayıkc1, 2009).

Table 1. Chemical content of aluminum ingot (\% wt.)

\begin{tabular}{ccccccc}
\hline $\mathrm{Si}$ & $\mathrm{Mg}$ & $\mathrm{Ti}$ & $\mathrm{Mn}$ & $\mathrm{Fe}$ & $\mathrm{Zn}$ & $\mathrm{Al}$ \\
\hline 7.20 & 0.392 & 0.12 & 0.001 & 0.18 & 0.005 & 92.10 \\
\hline
\end{tabular}

Figure 2 (a-b) shows the vibration device and the metal mold used in the casting process. The metal mold has three different cross-section thicknesses of 5, 10, $20 \mathrm{~mm}$. The mold steps are square prism shaped and the surface areas are equal and the size of each step is $40 \times 40 \mathrm{~mm}$. Variable crosssectional thickness allowed the investigation of the effects of mechanical vibration and grain refiner at different solidification rates.

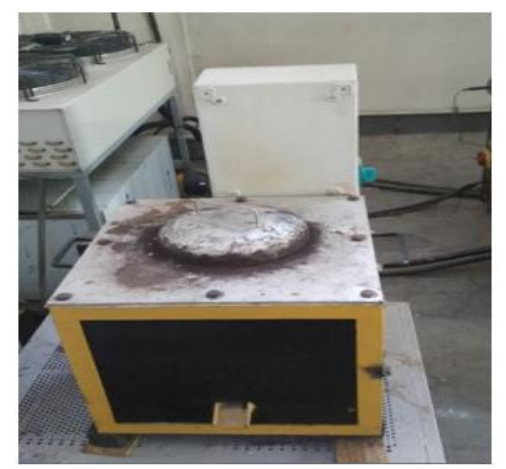

(a)

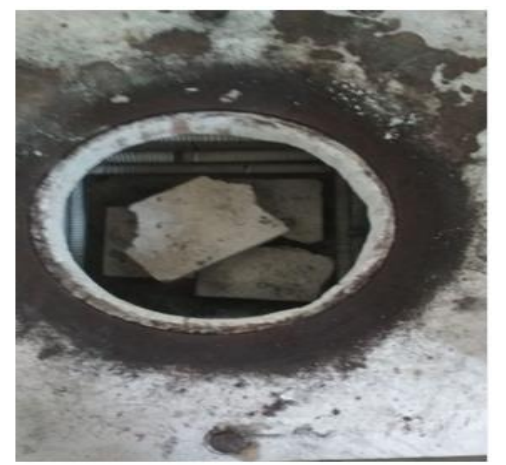

(b)

Figure 1. (a) Resistance furnace (b) A15Ti1B master alloy

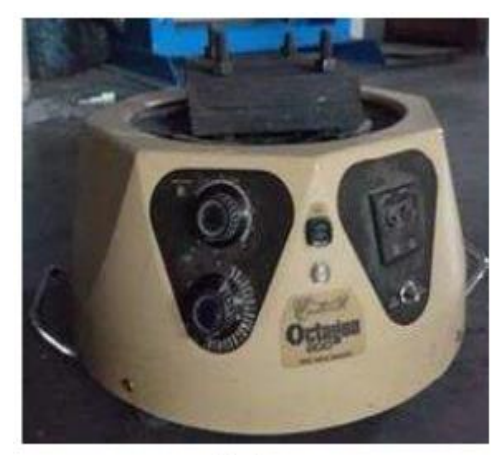

(a)

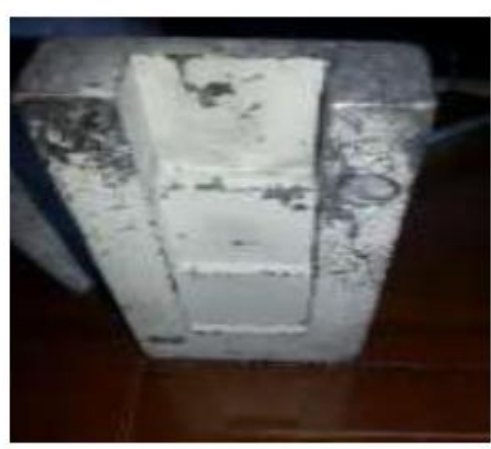

(b)

Figure 2. (a) Vibration device (b) Casting mold 
To increase the solidification time, casting mold is preheated to $400{ }^{\circ} \mathrm{C}$. The preheated mold taken from the furnace was then placed on the vibration device producing mechanical vibration at a constant frequency of $50 \mathrm{~Hz}$ and amplitude of $1.5 \mathrm{~mm}$ shown in Figure 2a. The metal in the step mold Figure $2 \mathrm{~b}$ was vibrated on the device for 90 seconds to solidify.

In order to examine the changes in the micrograph of the casting product seen in Figure 3 , the cast specimens were cut from the step level and cut in the middle and grinded then polished with $1 \mu \mathrm{m}$ diamond paste.

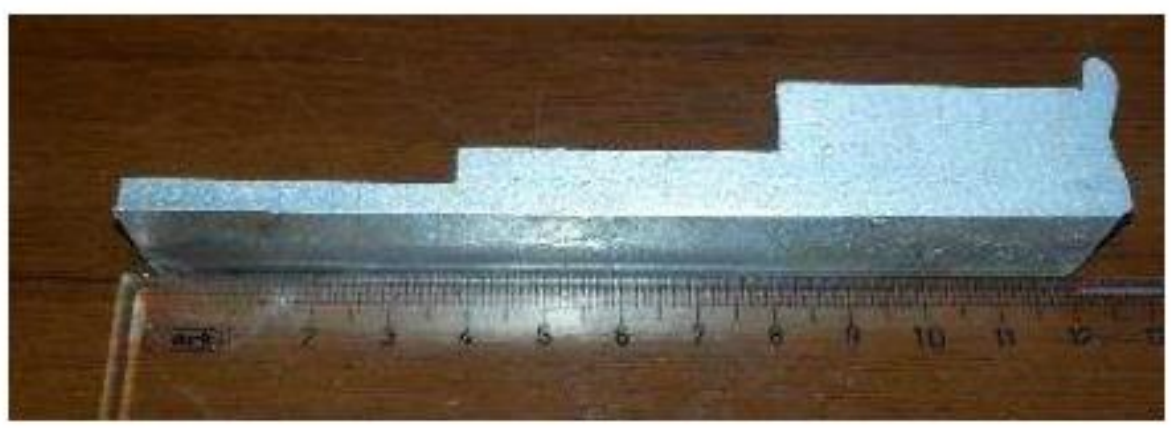

Figure 3. Cast specimen

Firstly, the distance between the secondary dendrite arms (SDAS) and the length of the secondary dendrite arms (SDAL) were measured by means of optical microscope images. Then, EDS analysis of the samples was made by scanning electron microscope (SEM). In addition, hardness measurements of the samples were made by Brinell method and the relationship between the microstructure and hardness values was tried to be revealed.

Table 2 shows the spectroscopic analysis of the cast specimens. In the sample names, the first numbers $(1,2,3)$ show $\% \mathrm{Ti}$ content $(0.1,0.2$ and $0.3 \%)$ respectively, and the other figure indicates that they are without vibration (0) or vibrated (1).

Table 2. Chemical compositions of the cast specimens (\% wt.)

\begin{tabular}{ccccccc}
\hline Element & Al 1-0 & Al 2-0 & Al 3-0 & Al 1-1 & Al 2-1 & Al 3-1 \\
\hline Sample & 7.08 & 6.83 & 6.73 & 7.04 & 7.03 & 6.85 \\
$\mathrm{Si}$ & 0.0717 & 0.0292 & 0.0507 & 0.0359 & 0.0339 & 0.0287 \\
$\mathrm{Fu}$ & 0.00384 & 0.00244 & 0.00311 & 0.00330 & 0.00259 & 0.00273 \\
$\mathrm{Mn}$ & 0.00582 & 0.00581 & 0.00595 & 0.00571 & 0.00568 & 0.00593 \\
$\mathrm{Mg}$ & 0.0936 & 0.191 & 0.188 & 0.155 & 0.203 & 0.209 \\
$\mathrm{Zn}$ & $<0$ & $<0$ & $<0$ & $<0$ & $<0$ & $<0$ \\
$\mathrm{Ni}$ & 0.0170 & 0.0174 & 0.0191 & 0.0168 & 0.0169 & 0.0171 \\
$\mathrm{Cr}$ & 0.00375 & 0.00582 & 0.00560 & 0.00366 & 0.00302 & 0.00434 \\
$\mathrm{~Pb}$ & 0.0129 & 0.0135 & 0.0123 & 0.0120 & 0.0122 & 0.0144 \\
$\mathrm{Sn}$ & 0.0238 & 0.0285 & 0.0268 & 0.0240 & 0.0252 & 0.0335 \\
$\mathbf{T i}$ & $\mathbf{0 . 1 7 0}$ & $\mathbf{0 . 2 4 7}$ & $\mathbf{0 . 3 0 7}$ & $\mathbf{0 . 1 7 7}$ & $\mathbf{0 . 2 3 9}$ & $\mathbf{0 . 3 6 0}$ \\
$\mathrm{Na}$ & $<0$ & $<0$ & $<0$ & $<0$ & $<0$ & $<0$ \\
$\mathrm{Sr}$ & 0.00016 & 0.00024 & 0.00062 & 0.00013 & 0.00033 & 0.00086 \\
$\mathrm{~V}$ & 0.0194 & 0.0232 & 0.0224 & 0.0196 & 0.0209 & 0.0273 \\
$\mathrm{Zr}$ & 0.00148 & 0.00171 & 0.00128 & 0.00150 & 0.00141 & 0.00185 \\
$\mathrm{Al}$ & 92.49 & 92.56 & 92.63 & 92.51 & 92.41 & 92.44 \\
\hline
\end{tabular}




\section{RESULTS AND DISCUSSION}

SDAS and SDAL values of non-vibrated and vibrated samples were measured depending on the thickness of sections. Figures 4, 5 and 6 show the variations of vibrated and non-vibrated micrograph of castings of different cross-sectional thicknesses of $0.1 \%, 0.2 \%$ and $0.3 \% \mathrm{Ti}$ additions respectively.
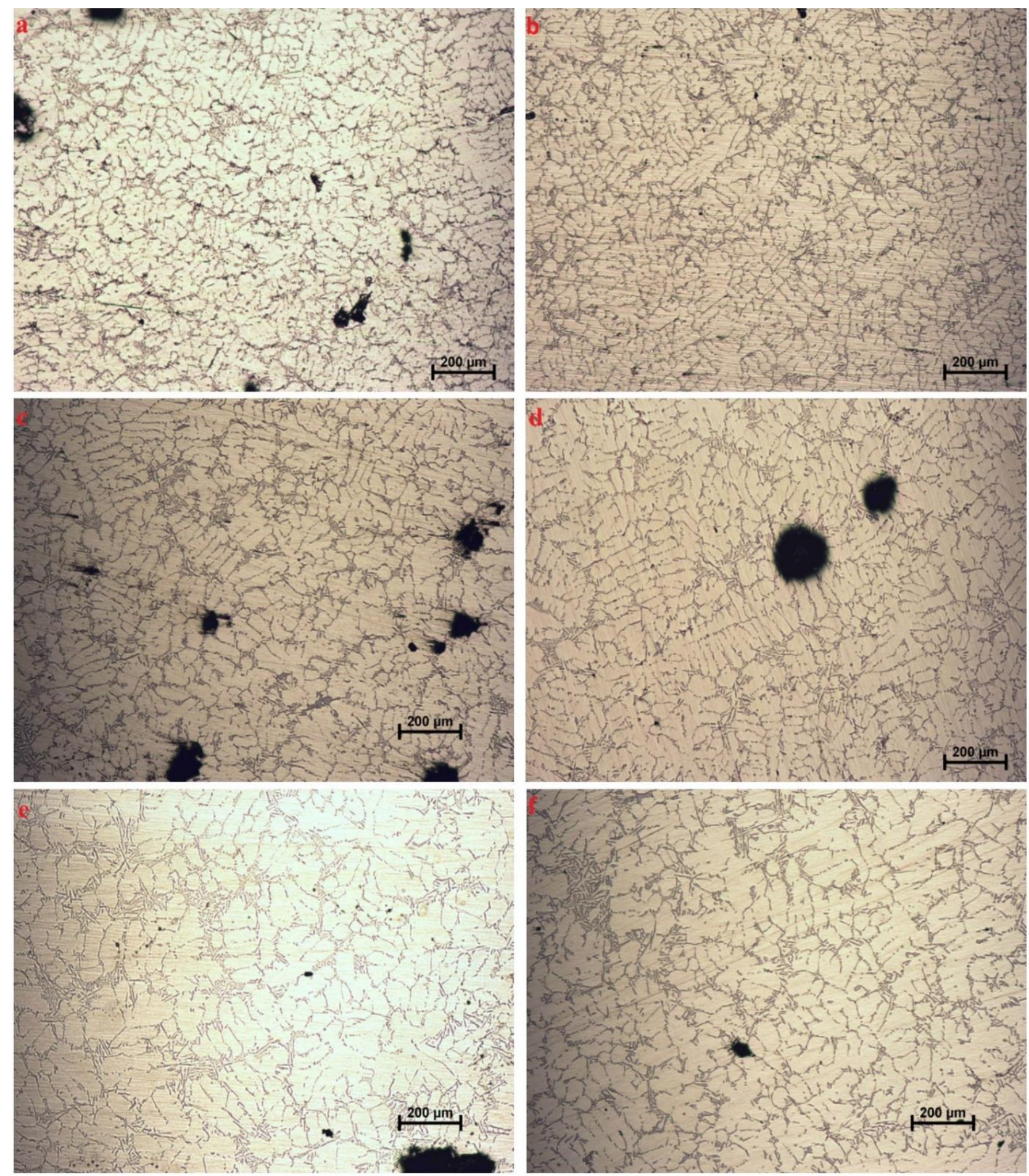

Figure 4. Micrograph images of cast samples with $0.1 \% \mathrm{Ti}$ added; a, c, e respectively thin, medium, heavy section nonvibrated, b, d, f respectively thin, medium, heavy sections of vibrated specimens 

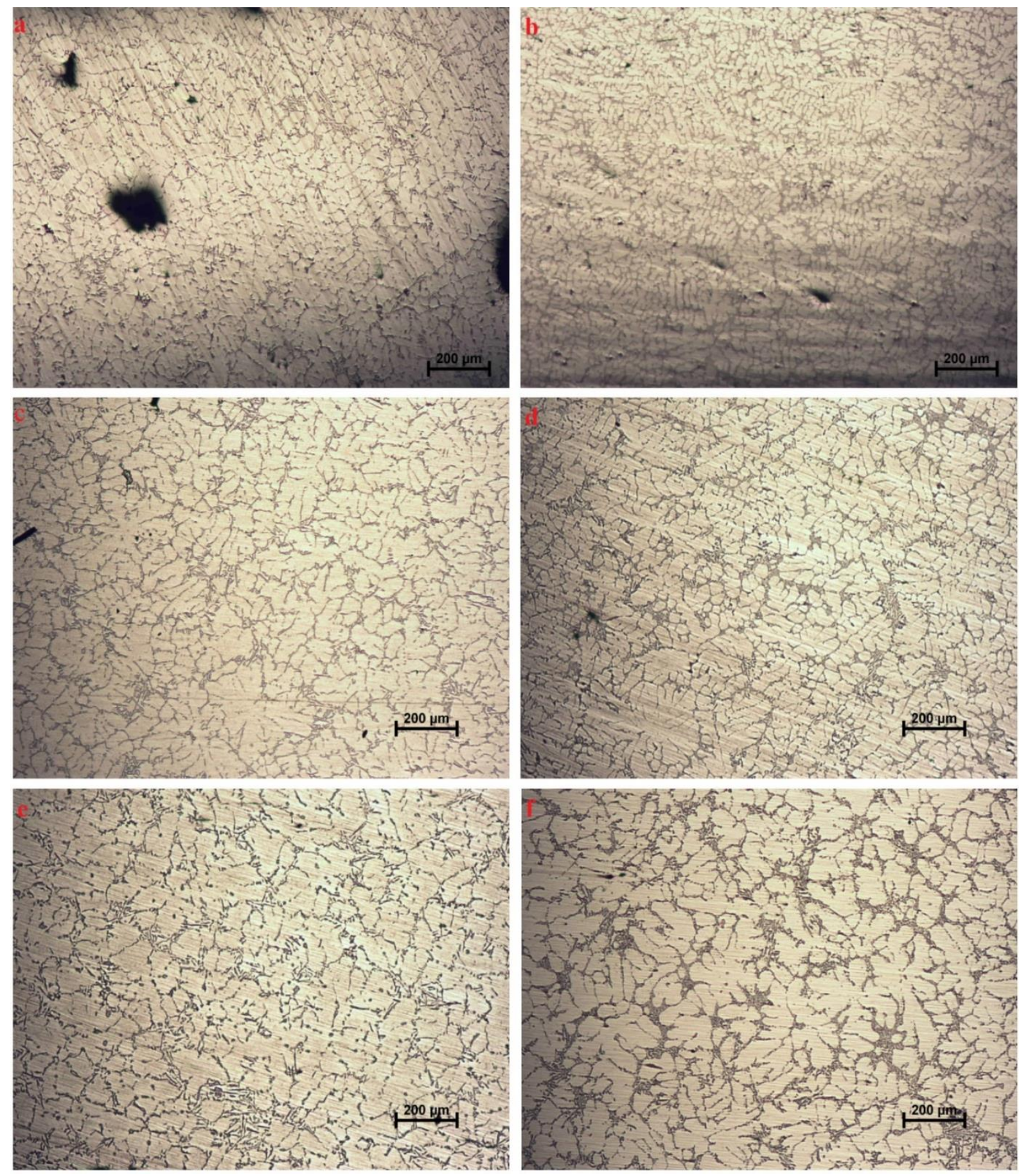

Figure 5. Micrograph images of cast samples with $0.2 \% \mathrm{Ti}$ added; a, c, e respectively thin, medium, heavy section nonvibrated, $\mathbf{b}, \mathbf{d}, \mathbf{f}$ respectively thin, medium, heavy sections of vibrated specimens

As shown in Figures 4, 5 and 6 as the titanium content increases, the number of grains in both non-vibrated and vibrated samples increase as the cross-sectional thickness decreases. Some researchers have reported that the rate of porosity decreases with vibration and contrast. In these studies, it is known that the porosity in the structure of casting products in the alloy systems which solidify under the effect of mechanical vibration at high cooling rate is caused by the hydrogen dissolved in the metal liquid and the insufficient mass feeding into the spaces between the dendrite arms of the liquid ( Taghavi et al. 2011 ). This increase was higher in vibrated samples due to the effect of spherical and broken dendrite arms. As can be seen again in the non-vibrating samples, a decrease in the porosity density was observed as the cross-sectional thickness increased, but no change in the size of the existing porosities could be 
detected. On the other hand, a significant decrease in porosity was observed in casting samples made under vibration and a significant decrease was observed in the existing porosity size. This reduction in the number and size of porosity provides for improved structural integrity as well as improved mechanical properties of the casting product.
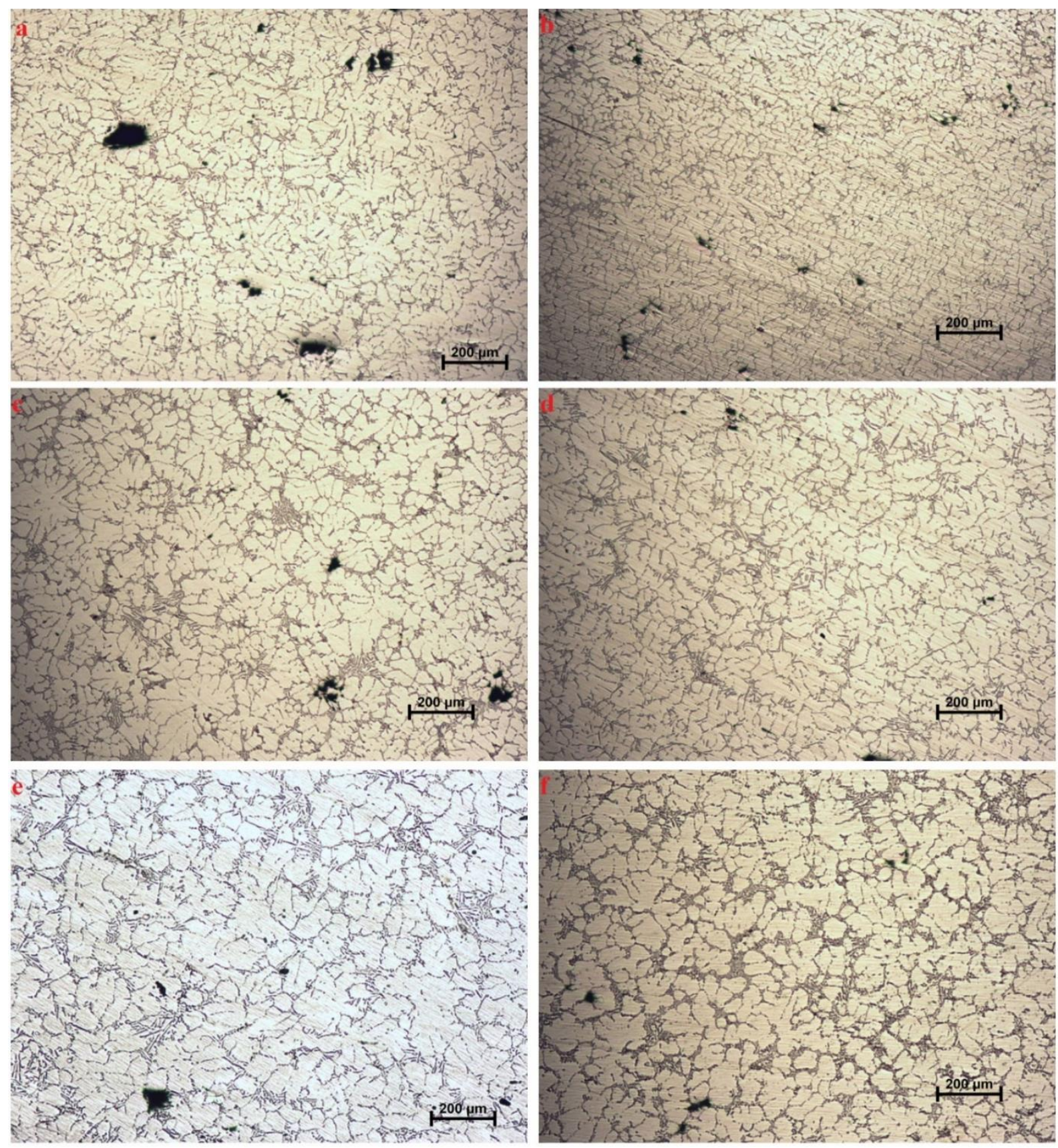

Figure 6. Micrograph images of cast samples with $0.3 \% \mathrm{Ti}$ added; a, c, e respectively thin, medium, heavy section nonvibrated, b, d, f respectively thin, medium, heavy sections of vibrated specimens

Vives has demonstrated that in continuous casting of aluminium alloys, electromagnetic vibrations could be effective on being refined of the microstructures ( Vivés et al., 1993 ). Also, same frequency, $50 \mathrm{~Hz}$ was used to evaluate $1 \mathrm{XXX}$ and $2 \mathrm{XXX}$ aluminium alloys. Extensive grain refinement was succesfully obtained both alloys. (Wu, et al., 2008 ) has conducted mechanical vibration on semisolid slurry of aluminium alloy. It is procured that alloy has become more globular, and also grains were decreased from 125 to $90 \mu \mathrm{m}$. ( Limmaneevichitr, et al., 2009) has studied producing semi-solid alloy 
routes via mechanical vibration as well. They have reported that average grain size of the primary Aldendrites has become more finer and globular with increasing degree of vibration.

In Figure 7 and Figure 8 scanning electron microscopy images and EDS analysis are given. All samples were examined and the most significant differences were observed in casting samples containing $0.2 \%$ and $0.3 \%$ Ti. In both Figure 7 and 8, it is seen that the aggregated Ti element rich regions have obtained and this demonstrated with EDS analysis in the samples containing grain refiner 0.2 and $0.3 \% \mathrm{Ti}$, respectively. Possible intermetallic phase could be $\mathrm{TiAl}_{3}$, which is major actor on grain refining of aluminim alloys. Clustering increases with increasing $\mathrm{Ti}$ content in the alloy and also, in SEM micrographs (Fig 7-8) clustering increased in Figure 8 significantly in samples containing $0.3 \%$ Ti. It was concluded that the increase in Ti concentration in the melt could increase the grain growth inhibitory parameters, and thus benefit from the final grain refinement effect on pure Al grains. With this grain refinement effect, toughness and strength can be increased in alloy systems ( Vivés, 1993 ).

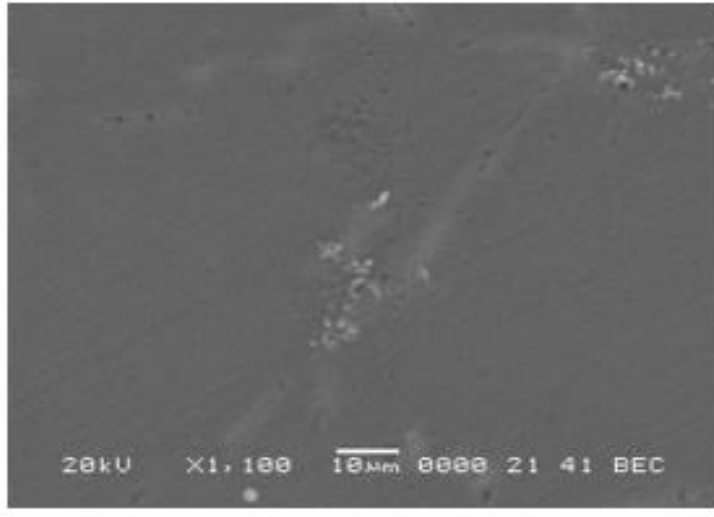

(a)

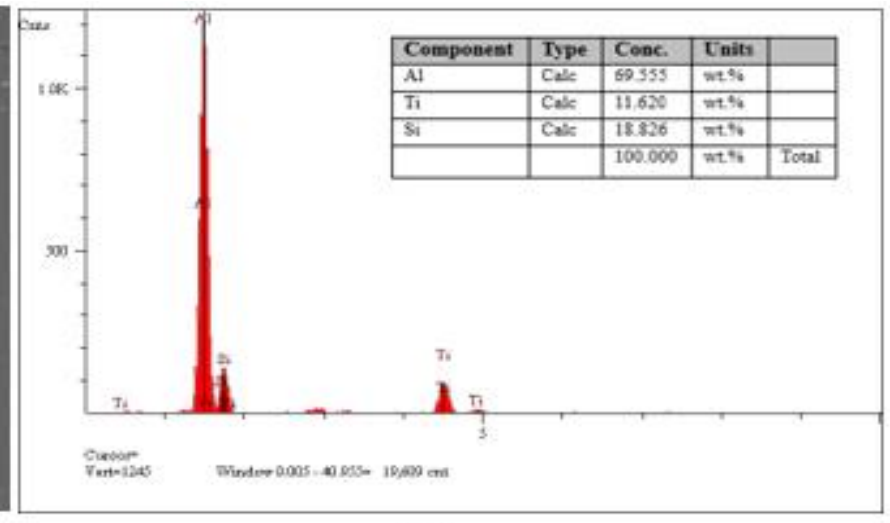

(b)

Figure 7. 0.2 \% Ti of sample (a) SEM images and (b) EDS analysis

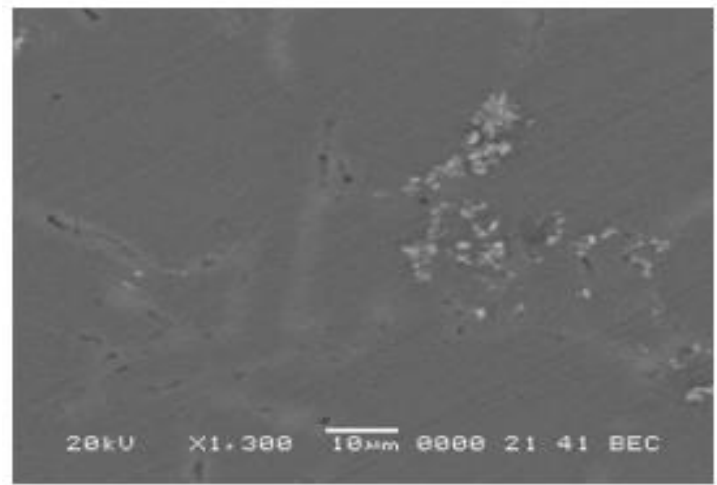

(a)

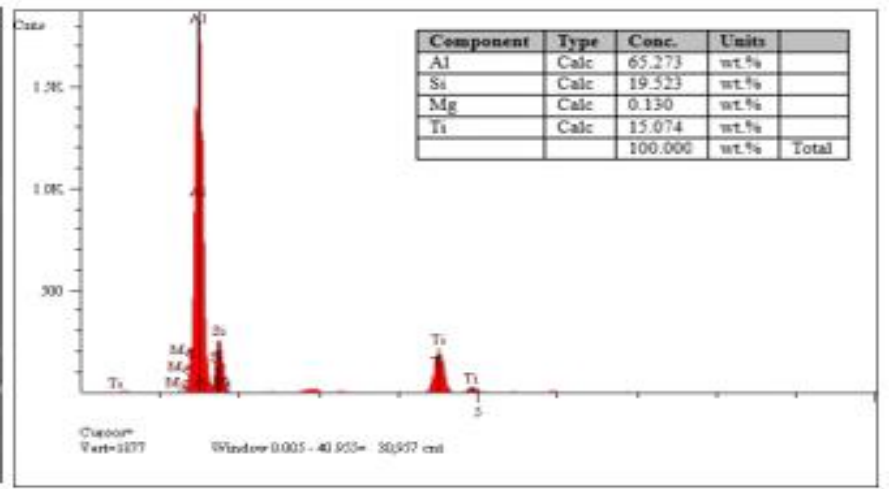

(b)

Figure 8. $0.3 \% \mathrm{Ti}$ of sample (a) SEM images and (b) EDS analysis

The first phase formed when solidification begins is the primary aluminium phase with dendritic morphology ( Yüksel, 2018 ). The graphics shown in Figure 9, 10 and 11 are intended to draw attention to the relationships between them rather than numerical values. Figures $9 a, b$, and c show the SDAS changes with respect to varying Ti ratios for non-vibrated and vibrated castings. When Ti ratio was over $0.3 \%$, it had an effect on SDAS. In addition to that, the application of vibration caused the further decrease on SDAS. The most significant effect of vibration on the SDAS value was found in the casting containing $0.2 \% \mathrm{Ti}$. SDAS increases from thin section to thick section due to decreasing cooling rate. During mechanical vibration application, coarse dendrite structures turn into fine and uniformly matched 
particles. On the other hand, the size, morphology and distribution of the $\alpha$-Al primary phase and eutectic silicon particles, as well as SDAS, have been significantly improved and the degree of grain increase has increased with increasing wall thickness ( Jiang et al., 2014; Uludağ et al., 2017; Çolak, 2019 ).

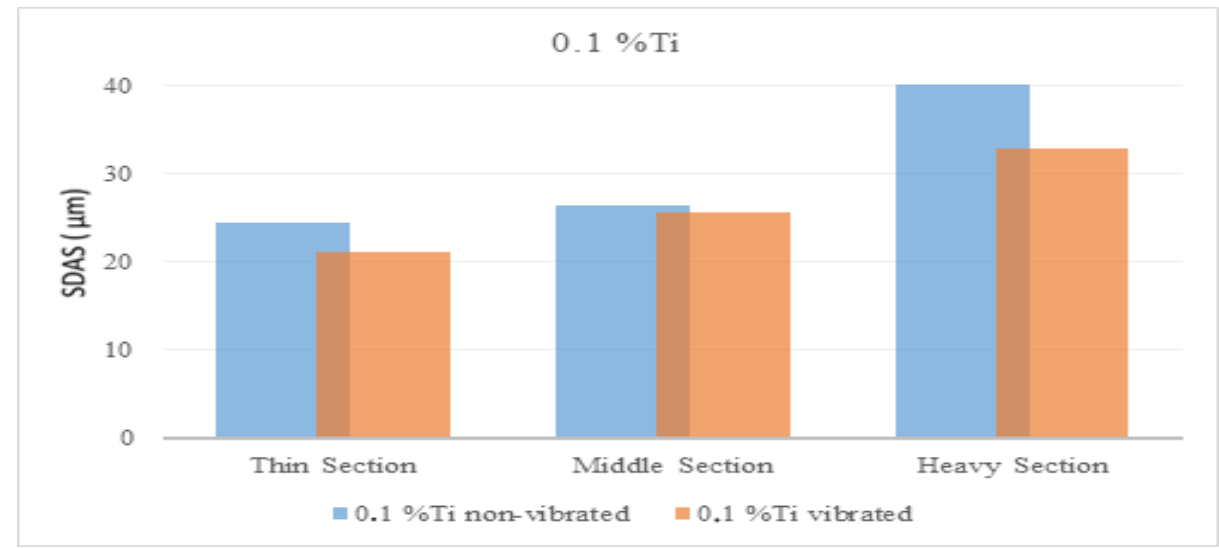

(a)

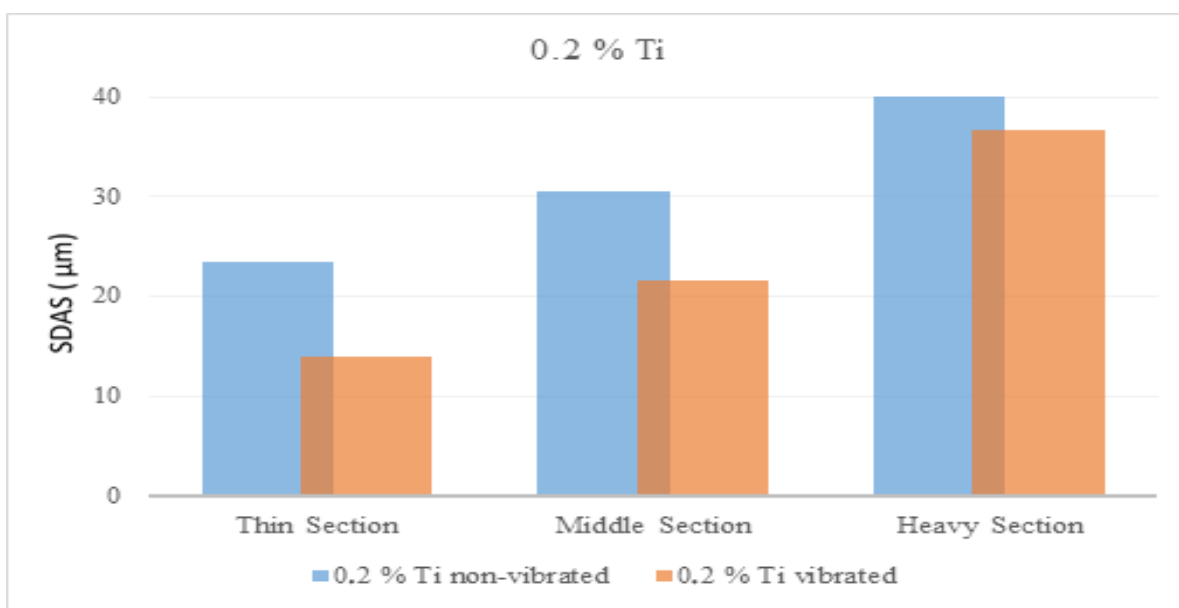

(b)

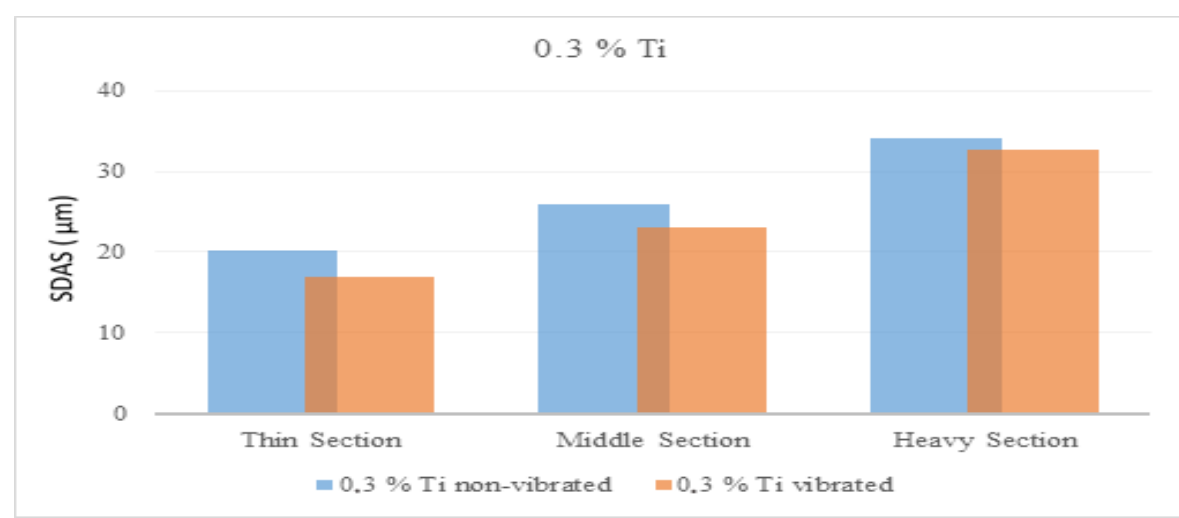

(c)

Figure 9: Non-vibrated and vibrated SDAS measurement comparison of castings containing a) $0.1 \% \mathrm{Ti}$, b) $0.2 \% \mathrm{Ti}$, c) $0.3 \% \mathrm{Ti}$

Figures $10 \mathrm{a}, \mathrm{b}$ and $\mathrm{c}$ show the effect of mechanical vibration on the distance values between secondary dendrite arms (SDAL) in grain refined castings. The SDAL value shows a significant reduction in the $0.3 \% \mathrm{Ti}$ addition rate, similar to SDAS. It is seen that the addition of Ti is not effective and the vibration effect decreases SDAL at $0.1 \%$ and $0.2 \%$. Similar to SDAS, as the thickness of section increases, the SDAL value increases with increasing solidification time. 


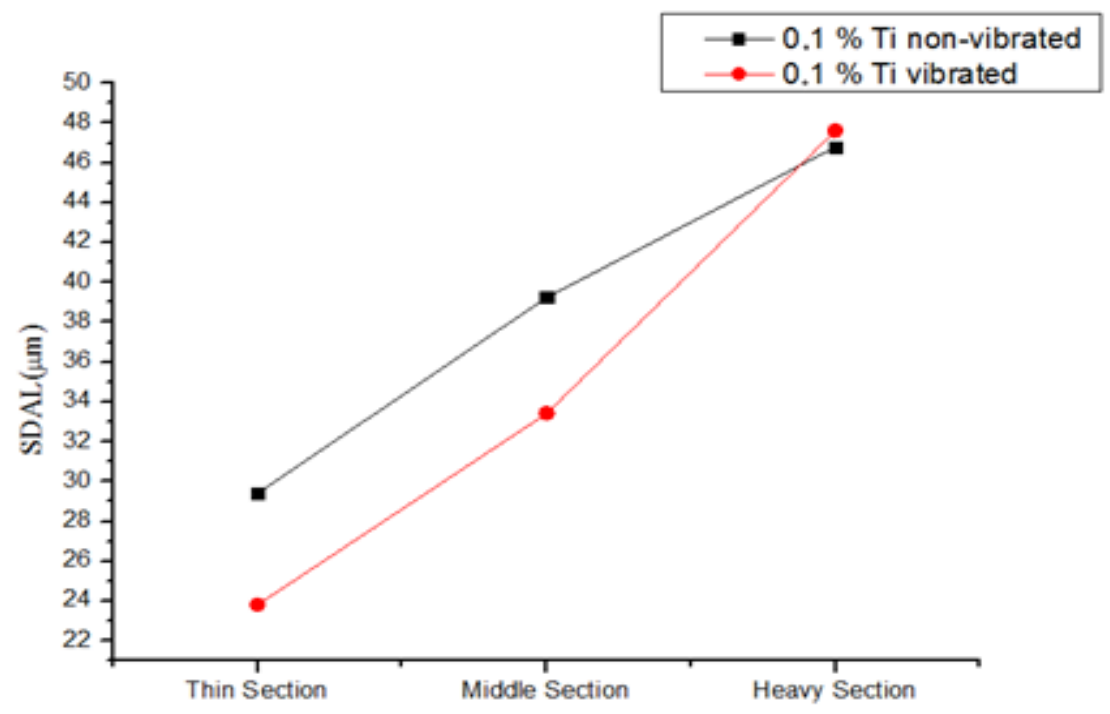

(a)

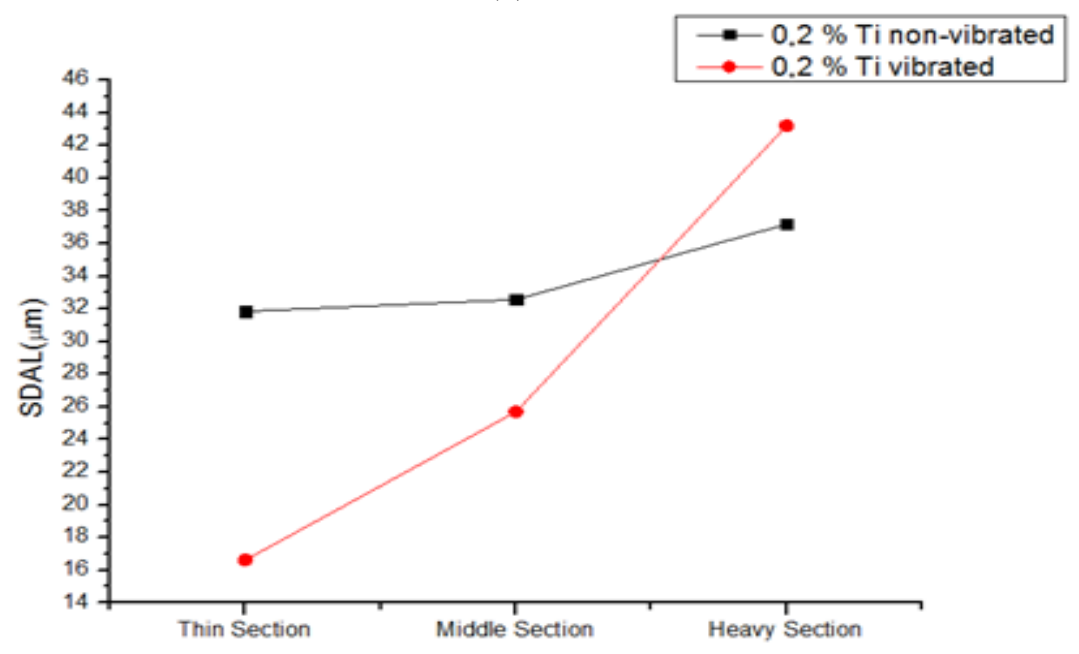

(b)

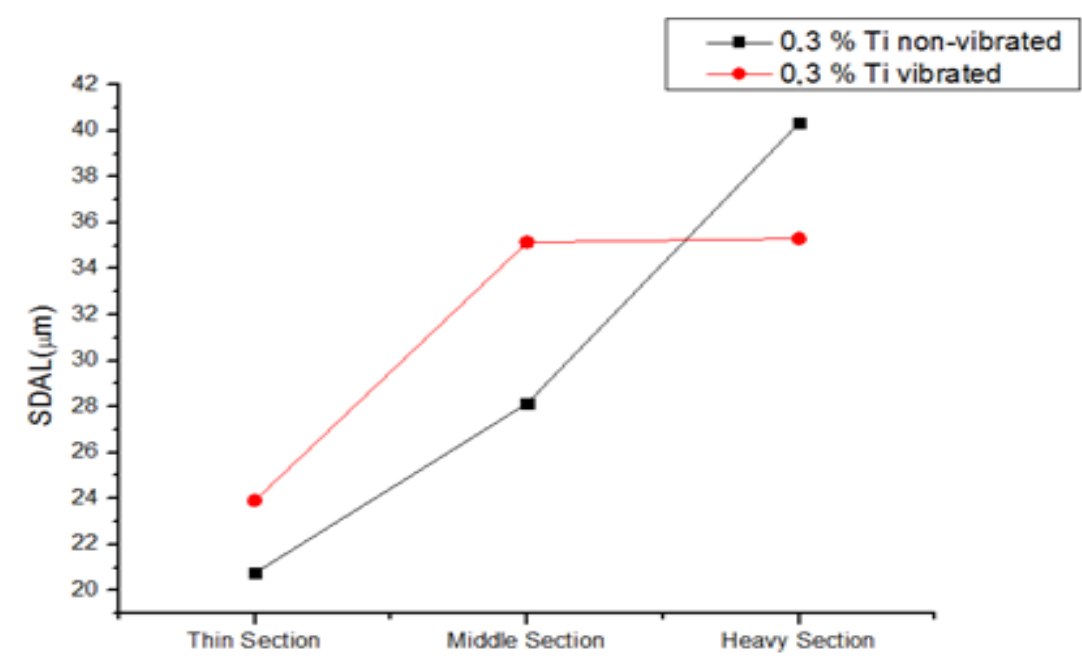

(c)

Figure 10: Non-vibrated and vibrated SDAL measurement comparison of castings containing a) $0.1 \% \mathrm{Ti}$, b) $0.2 \% \mathrm{Ti}$, c) $0.3 \% \mathrm{Ti}$ 
Figures $11 \mathrm{a}, \mathrm{b}$, and c show hardness values for different non-vibrated and vibrated castings with different Al5Ti1B additions depending on the section thickness. It can be seen that as the Ti content increases, hardness of the sample increases aswell in both casting conditions. It is observed that mechanical vibration increases hardness even more in castings with $0.1 \% \mathrm{Ti}$ added. However, at 0.2 and $0.3 \% \mathrm{Ti}$ addition rates, the effect of mechanical vibration on hardness increase was less than that of the $\mathrm{Ti}$ added castings alone. However, it has been found that with increasing cross-sectional thickness, hardness values decrease with varying cooling rate depending on cross-sectional thickness. In addition to this, hardness values of thick sections have been influenced by the fact that this section is the last solidifying zone, which acts as a riser, and hence the formation of shrinkage cavities in this section. It has been found that the casting conditions, whether vibrated or not, have no significant effect on hardness values.

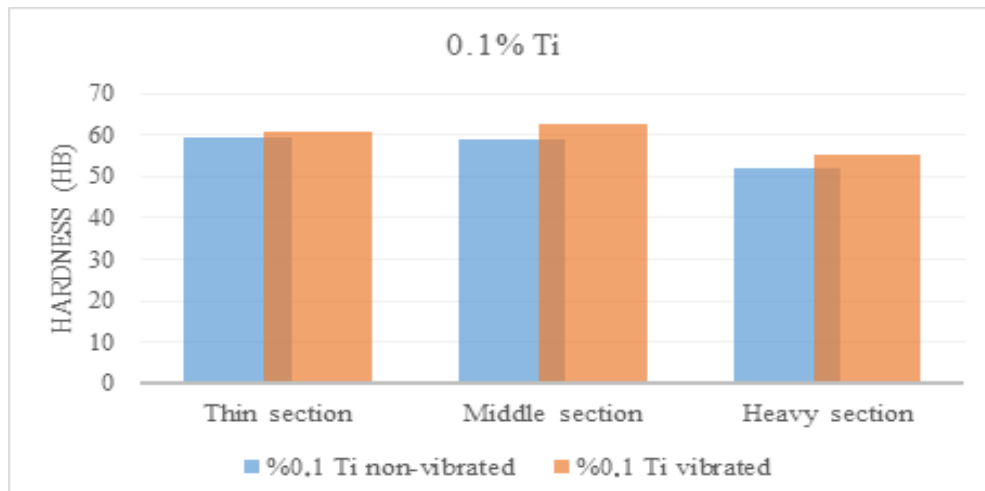

(a)

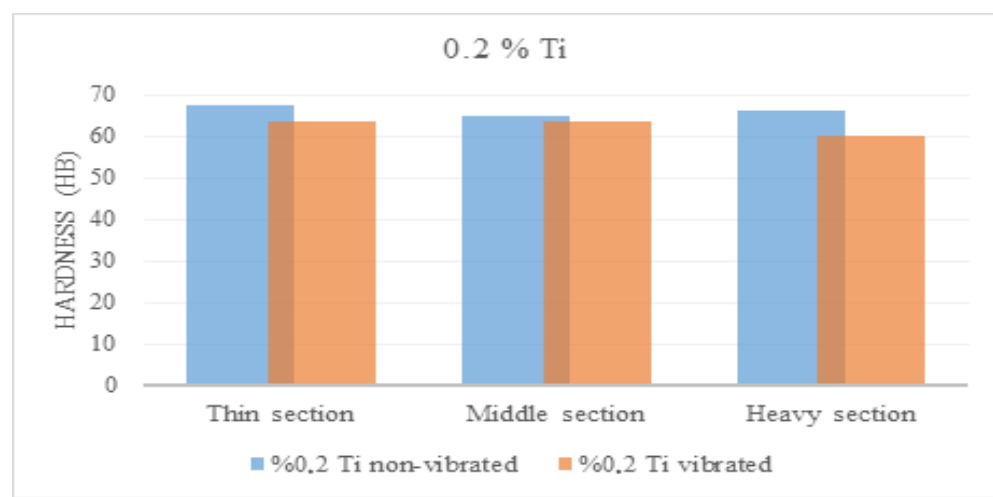

(b)

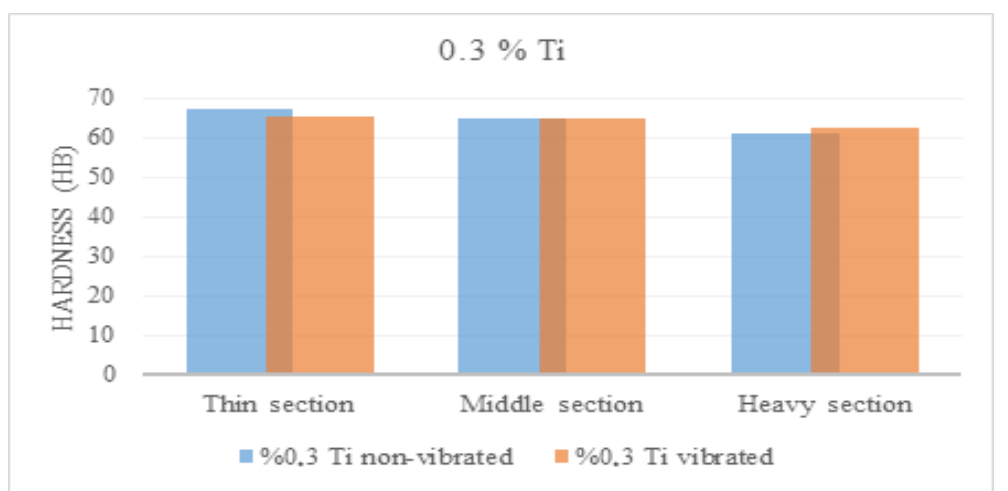

(c)

Figure 11: Non-vibrated and vibrated cross-section hardness changes of castings containing a) $0.1 \% \mathrm{Ti}$, b) $0.2 \% \mathrm{Ti}$, c) $0.3 \% \mathrm{Ti}$ 


\section{CONCLUSIONS}

This study was carried out in order to improve the properties of $\mathrm{Al}$ alloys produced by casting method and to show the combined effect of grain refining mechanisms that cause microstructure changes.

It was observed that the vibration mechanism, titanium ratio and cooling rate varying depending on the thickness of cross-section were so effective on microstructural changes.

When titanium content was $0.3 \%$, it had a positive effect on SDAS and SDAL. Furthermore, when Ti ratio is $0.1 \%$ and $0.2 \%$, mechanical vibration was so effective on SDAS and SDAL. Also, SDAS and SDAL values decreased in both vibrated and non-vibrated conditions with increasing cooling rate.

In the non-vibrated specimens, porosity rates were decreased, as the thickness of castings were increased. Same situation was obtained in the vibrated specimens but both rates and magnitudes of the porosity were decreased significantly. Considering all the casting conditions, applying vibration to the castings assisted to decrease dramatically both dimensions and amount of the porosity.

Although no significant differences were observed in hardness measurements, it was observed that hardness increased with vibrations at the rate of $0.1 \mathrm{Ti}$, whereas the vibration had no effect on hardness at the rates of 0.2 and $0.3 \mathrm{Ti}$, or a negative effect was observed. SDAS, SDAL and hardness values decreased due to the reduced cooling rate as the section thickened.

\section{REFERENCES}

Chirita G, Stefanescu I, Soares D, Silva S, 2009. Influence of vibration on the solidification behavior and tensile properties of an Al-18 wt \%Si alay. Materials and Design 30:1575-1580.

Çolak M, Kayıkcı R, 2009. Alüminyum döküm alaşımlarında TiB ilavesi ile tane inceltmede bekletme zamanının tane boyutuna etkisinin incelenmesi. 4. Alüminyum Sempozyumu, 15-16 Ekim 2009, İstanbul.

Çolak M, Kayıkcı R, 2009. A356 Döküm Alaşımında Elektromanyetik Karıştırmanın Mikroyapı ve Mekanik Özelliklere Etkisi, Pamukkale Üniversitesi Mühendislik Bilimleri Dergisi, 15 (3): 345-351.

Çolak M, Balc1 M, 2016. Study on effect of the mechanical vibration on solidification in process of A356 aluminium alloy casting. International conference on engineering and natural science, 24-28 May 2016, Sarajevo.

Çolak M, 2019. Modification of eutectic Al-Si alloys by $\mathrm{Sr}$ and CuSn5. Materials Research Express 6 (10).

Edwards L, 2004. Strategic substitution of new materials for old applications in automotive product development. Materials and Design (25):529-533.

Hong-min G, Zhang A, Yang X, Yan M, 2014. Grain refinement of $\mathrm{Al}-5 \% \mathrm{Cu}$ aluminum alloy under mechanical vibration using meltable vibrating probe. Trans. Nonferrous Met. Soc. China (24):2489-2496.

Ibarra G, 1999. A thesis submitted to the Faculty of Graduate Studies and Research in partial fulfillment of the requirements of the degree of Doctor of Philosophy, Department of Mining and Metallurgical Engineering McGill University, Master Tesis( Printed)

Jiang W, Fan Z, Cheen X, Wang B, Wu H, 2014. Combined effects of mechanical vibration and wall thickness on microstructure and mechanical properties of A356 aluminum alloy produced by expendable pattern shell casting. Materials Science and Engineering A (619):228-237.

Dönmez A, Çukur A, Kurban F, Kaba M, Çubuklusu E, Aybarç U, Malayoğlu U, Birol Y, 2017. Tane inceltme işlemlerinin iyileştirilmesi ve alçak basınçlı döküm sistemleriyle AlSi5Mg0.3 alaşımlı jant üretimi. Tüdoksad Akademi 9. Döküm Kongresi 20-21 Ekim 2017, Eskişehir.

Koşatepe A, Kabil A, Yüksel Ç, 2019. Effect of TiBAl Addition on Electrical Conductivity of Al7Si0,3Mg Alloy in the Vibrated Mold Casting. The International Conference on Materials Science, Mechanical and Automotive Engineerings and Technology, 21-23 june 2019, Cappadocia. 
Lieserberg O, Drossel G, 2001. Casting Aluminium Hand Book 2. Aluminium Verlag GMBH, Düsseldorf, 386388-406.

Limmaneevichitr C, Pongananpanya S, Kajornchaiyakul J, 2009. Metallurgical structure of A356 aluminum alloy solidified under mechanical vibration: An investigation of alternative semi-solid casting routes, Materials and Design (30):3925-3930.

Peres D, Siqueira A, Garcia A, 2004. Macrostructural and microstructutal development in al-si alloys directionally solidified under unsteady-state conditions. Journal of Alloys and Compounds (381):168-181.

Puga H, Costa S, Ribeiro S, Prokic M, 2011. Influence of ultrasonic melt treatment on microstructure and mechanical properties of AlSi9Cu3 alloy. Journal of Materials Processing Technology (211):1729- 1735 .

Sayuti M, 2016. Metal matrix composite products by vibration casting method. University Putra Malaysia, Selangor, Malaysia.

Taghavi F, Saghafian H, Khrrazi Y, 2009. Study on the effect of prolonged mechanical vibration on the grain refinement and density of A356 aluminum alloy. Materials and Design (30):1604-1611.

Tunçay T, 2012. A356 alüminyum döküm alaşımlarında sıvı metal hareketinin mikroyapı ve mekanik özellikleri üzerine etkisinin incelenmesi. Gazi University Graduate School of Natural and Applied Sciences, Doctoral Thesis(Printed)

Uludağ M, 2016. Yönlendirilerek dökülmüş al-si alaşımlarında tane incelticilerin porozite oluşumu üzerindeki rolü. Published in 4th International Symposium on Innovative Technologies in Engineering and Science, 35 November 2016, Alanya/Antalya.

Uludağ M, Kocabaş M, Dışpınar D, 2017. Effect of Sr and Ti Addition on the Corrosion Behaviour of Al-7Si$0.3 \mathrm{Mg}$ Alloy. Archives of Founddry Engineering 125-130.

Wu S, Xie L, Zhao J, Nakae H, 2008. Formation of non-dendritic microstructure of semi-solid aluminum alloy under vibration. Scripta Materialia (58):556-559.

Vivés Ch, 1993. Effects of electromagnetic vibrations on the microstructure of continuously cast aluminum alloys. Materials Science and Engineering A (173):169-172.

Yüksel Ç, 2018. Titreşimli katılaştırmanın birincil ve ikincil Al7Si0,3Mg alüminyum alaşımlarının içyapısına etkisi. Omer Halisdemir University Journal of Engineering Sciences 7(2):986-992. 